\title{
Fibrous Osteodystrophy
}

National Cancer Institute

\section{Source}

National Cancer Institute. Fibrous Osteodystrophy. NCI Thesaurus. Code C139147.

The replacement of cortical bone by fibrous connective tissue that may be caused by parathyroid hormone-mediated bone resorption with secondary fibroplasia. 